\title{
The European Convention of Human Rights as a Kantian cosmopolitan legal order
}

\author{
G A R R E T T W A L L A C E B R O W N \\ University of Leeds, School of Politics and International Relations, Leeds, LS2 9JT, \\ United Kingdom
}

Email: g.w.brown@leeds.ac.uk

M A D S A N D N A S

Faculty of Law, University of Oslo, Karl Johans Gate 47, 0162 Oslo, Norway

Email: Mads.andenas@jus.uio.no

\begin{abstract}
In A Cosmopolitan Legal Order: Kant, Constitutional Justice and the European Convention on Human Rights, Alec Stone Sweet and Clare Ryan argue that there has been the emergence of, and increasing prospects for, a cosmopolitan legal order based on the Convention. This symposium aims to engage with, and to better explore, the theoretical implications and practical legal ramifications of their argument. In doing so, this first article acts as a general introduction to the symposium, laying out the major arguments of the book as well as arguments presented by the symposium contributors. Moving beyond the summative, this introduction also situates A Cosmopolitan Legal Oder within broader debates in global constitutionalism, while defending its use of Kant's cosmopolitan theory. Lastly, it explores some of the key implications and challenges that arise from the symposium itself, rooting these insights within the current context of antiglobalism, nationalism, populism and neo-sovereigntism, and the corresponding necessity for a more transitional and pluralistic response as offered in A Cosmopolitan Legal Order.
\end{abstract}

Keywords: cosmopolitanism; European Convention of Human Rights; Immanuel Kant; legal cosmopolitanism; public right

\section{Introduction}

The twenty-first century has witnessed the rise of two antithetical movements in international legal theory and practice. On one side, there has been a steady increase and interest in legal cosmopolitanism and corresponding narratives 
on an emerging global constitutionalism. ${ }^{1}$ On the other side, there has been a pronounced resurgence of what Peter Shapiro has labelled neosovereigntism, ${ }^{2}$ with stringent claims for national self-determination, in which states have both a legal right and a moral duty to opt out of any international covenant that restricts and/or comes into conflict with democratic self-legislation. ${ }^{3}$ This latter movement, which grew under George W. Bush, ${ }^{4}$ and has accelerated with the rise of populism in the United States and Europe, is often seen as directly opposed to ideas of a cosmopolitan legal order. ${ }^{5}$ Although there are arguments to suggest that the binary between state self-determination and global constitutionalism is theoretically overplayed, ${ }^{6}$ in practice present-day dynamics suggest a tension between globalization and globalism on one side, and particularism and the rise of antiglobalization sentiment on the other. This potential tension has been accelerated (or made more obvious) by the impact of international agreements and international courts on an unprecedented scale: the combined force of the World Trade Organization (WTO), the European Union (EU) with its Court of Justice of the European Union (CJEU), investment treaty agreements with arbitral tribunals, the European Court of Human Rights (ECtHR) itself with other regional courts, and the UN system, also empowering domestic courts in their review of national authorities from which political pushback can arise. Yet, beyond the political, this also illustrates that, along the way, international law and human rights acquired teeth.

It is against this current global backdrop that Alec Stone Sweet and Clare Ryan propose the emergence of, and increasing prospects for, a 'cosmopolitan legal order' based on the European Convention on Human

${ }^{1}$ Mads Andenas and Eirik Bjorge, A Farewell to Fragmentation: Reassertion and Convergence in International Law (Cambridge University Press, Cambridge, 2015); Garrett Wallace Brown, 'Cosmopolitanism and Global Constitutionalism' in Global Constitutionalism, edited by Anthony F Lang and Antje Wiener (Edward Elgar, Cheltenham, 2019).

2 Peter J Spiro 'The New Sovereigntists: American Exceptionalism and Its False Prophets' (2000) Foreign Affairs, 1-5 December.

3 John R Bolton and John Yoo 'Restore the Senate's Treaty Power' (2009) New York Times, 5 January; Jeremy A Rabkin, Law without Nations? Why Constitutional Government Requires Sovereign States (Princeton University Press, Princeton, NJ, 2005).

${ }^{4}$ Allen Buchanan and Russell Powell, 'Constitutional Democracy and the Rule of International Law: Are They Compatible?’ (2008) 16(3) The Journal of Political Philosophy 326.

${ }^{5}$ Richard Beardsworth, Garrett Wallace Brown and Richard Shapcott, The State and Cosmopolitan Responsibilities (Oxford University Press, Oxford, 2019).

${ }^{6}$ Garrett Wallace Brown, 'The Idea of Autonomy: Accountability, Self-determinism and What Normative Claims About Institutional Autonomy in Global Governance Should Mean' in International Organizations and the Idea of Autonomy, edited by Richard Collins and Nigel D White (Routledge, London, 2011).

7 Mads Andenas, 'Reassertion and Transformation: From Fragmentation to Convergence in International Law' (2015) 46(3) Georgetown Journal of International Law 685. 
Rights. ${ }^{8}$ In order to theoretically ground the ECtHR as a nascent form of legal cosmopolitanism, the authors propose an applied Kantian framework to determine a condition of global constitutional justice that is able to operate both within and beyond the state. By outlining a legal order that intersects with, and then transcends, both national and international law, the authors purposely attempt to navigate a course that offers state-based self-determined constitutionalism with a Kantian cosmopolitan purpose, thus carefully charting a middle position that might better satisfy cosmopolitans as well as their milder critics. ${ }^{9}$

Yet what is particular or even unique about the treatment presented in $A$ Cosmopolitan Legal Order is that it delivers equal parts of Kantian cosmopolitanism (Part I) and international legal analysis (Part II), representing a commanding piece of applied theory. This is different from previous attempts in legal cosmopolitanism, which have mostly focused on Kantian legal theory, ${ }^{10}$ providing only limited interventions in 'black letter' legal analysis. ${ }^{11}$ As a result, the book resides within, while empirically furthering, a Habermasian interpretation of 'international law with a cosmopolitan purpose'. After Between Facts and Norms ${ }^{12}$ Jürgen Habermas directed much of his attention to developing a cosmopolitan approach in the tradition of Kant's thinking. In doing so, Habermas addressed the role of the United Nations and the European Union, as well as the character of international law and international/European institutions, as representative of transitional 'stepping-stones' towards a CLO. ${ }^{13}$

${ }^{8}$ Alec Stone Sweet and Clare Ryan, A Cosmopolitan Legal Order: Kant, Constitutional Justice, and the European Convention on Human Rights (Oxford University Press, Oxford, 2018).

9 See Benhabib's discussion regarding this tension in this issue.

${ }^{10}$ Pauline Kleingeld, 'Kant's Cosmopolitan Law: World Citizenship for a Global Order' (1998) 2 Kantian Review 72; Georg Cavallar, The Rights of Strangers (Ashgate, Aldershot, 2002); Otfried Hoffe, Kant's Cosmopolitan Theory of Law and Peace (Cambridge University Press, Cambridge, 2006); Garrett Wallace Brown, Grounding Cosmopolitanism: From Kant to a Cosmopolitan Constitution (Edinburgh University Press, Edinburgh, 2009); Patrick Capps and Julian Rivers, 'Kant's Concept of International Law' (2010) 16(4) Legal Theory 229; Claudio Corradetti, 'Kant's Legacy and the Idea of a Transitional Jus Cosmopoliticum' (2016) 29(1) Ratio Juris 105.

${ }^{11}$ See (n 5), Chs 6 and 7; (n 8); David Hirsh, The Law Against Genocide: Cosmopolitan Trials (Taylor and Francis, London, 2012); Mads Andenas and Eirik Bjorge, 'The External Effects of National ECHR Judgments' (2012) NYU Jean Monnet Working Paper 07/12 and Mads Andenas and Eirik Bjorge, 'National Implementation of ECHR Rights: Kant's Categorical Imperative and the Convention' in Andreas Follesdal, Birgit Schlütter and Geir Ulfstein, The European Court of Human Rights in a National, European and Global Context (Cambridge University Press, Cambridge, 2011).

12 Jürgen Habermas, Between Facts and Norms (Polity Press, Cambridge, 1996).

13 Jürgen Habermas, 'Is There Still a Chance for the Constitutionalization of Public International Law?' in Jürgen Habermas, The Divided West (Polity Press, Cambridge, 2006) 115; Jürgen 
The importance of having greater applied balance, as represented by Stone Sweet and Ryan's book, cannot be stressed enough. This is because cosmopolitans and global constitutionalists are seemingly good bedfellows, where cosmopolitans need to be better applied global constitutionalists, while global legal constitutionalists need to be more explicitly moral and legal cosmopolitans. As argued elsewhere, 'global constitutionalism is inherently normative and clearly operates within the universalist and cosmopolitan lexicon . . . the problem, however, is that this interconnection and interrelation has remained under-explored and often taken for granted'. ${ }^{14}$

The expansion of international law and courts, and reactions against this expansion, have spurred a rich and unfocused scholarship from the perspective of different domestic legal disciplines, in particular constitutional law, international law and several other disciplines. Beyond the boundaries that divide law, political science and philosophy, a number of larger research projects have focused on familiar legitimacy matrices. They may provide critical perspectives, but they rarely offer much assistance when it comes to understanding and developing the international legal system and the responses in national law and politics. Domestic constitutional law often operates within a Hegelian concept of the state and law, where states' relationships with one another can only be external, dismissing classic universalism, Kant and the proposal for perpetual peace as a mere chimera. At the same time, Kantian concepts are seen as influential in many national legal traditions, and indeed are viewed as important to international legal orders such as the United Nations, the European Union and the European Convention on Human Rights. There is an openness towards Kantian legal theory and legal analysis, but little in the form of sophisticated applied analysis. The discussions on a European Constitution and the EU Charter of Rights reflect the same failures of scholarship and an openness to applied analysis. ${ }^{15}$

By presenting a balanced treatment of Kantian legal theory and international legal analysis, A Cosmopolitan Legal Order helps to advance a more comprehensive blueprint for how to locate and practically strengthen a plurality of existing legal orders towards a meaningful cosmopolitan condition. This may strengthen the theoretical foundation of the general discourse, including initiatives by states and judgments by courts. As Corradetti notes in his contribution to this symposium, this treatment of Kant reaffirms

\footnotetext{
Habermas, 'Konstitutionalisierung des Völkerrechts und die Legitimationsprobleme einer verfassten Weltgesellschaft', in Rechtsphilosophie im 21. Jahrhundert, edited by Winifried Brugger, Ulfrid Neumann and Stephan Kirste (Suhrkamp, Frankfurt, 2008) 360-62; David Held, Cosmopolitanism: Ideals and Realities (Policy Press, Cambridge, 2010).

${ }^{14}$ See (n 1) 94.

15 Mads Andenas and John Gardner 'Introduction: Can Europe Have a Constitution?' (2001) 12(1) King's College Law Journal 1.
} 
a more moderate 'transitional' reading of cosmopolitan law, one that can better satisfy state-based self-legislation as well as 'legitimize external relations of states among themselves'. In his contribution, Bjorge goes a step further, concluding that the ECtHR has established the only international legal order with the characteristics of a Kantian CLO, which he argues is well grounded in the legal tradition focused on courts. Again, in line with Habermas, Corradetti and Bjorge submit that such a transitional model, with sovereignty dispersed at different levels simultaneously, renders a process where domestic democratic processes can legitimize international public authority. ${ }^{16}$

Although it has been argued that Stone Sweet and Ryan may have conceded too much ground to states in their pluralist constitutionalism (see three different approaches to this tension: from Sadurski - they concede too much deferential legitimacy to states; Benhabib - potential compatibility via dialogic constitutionalism; and Corradetti - the CLO actually legitimizes participating states as representatives of a unifying will), given the tensions manifest in contemporary international relations, it could also be argued that this weaker transitional approach is practically needed, particularly if any form of cosmopolitan advancement is to gain traction.

For Stone Sweet and Ryan, a cosmopolitan legal order (CLO) is defined as a multi-level, transnational legal system in which: (1) justiciable rights are held by individuals; (2) all public officials bear an obligation to fulfil the fundamental rights of every person within their jurisdiction, without respect to nationality or citizenship; and (3) both domestic and transnational judges supervise how officials do so. What is distinctively Kantian about this order is that it fulfils three key principles underwriting Kant's moral and legal thought: first, that the ultimate unit of moral concern is the dignity of human beings and their agency as ends in themselves; second, that the moral status of freedom attaches to everyone equally under a coexisting multi-level condition of external freedom; and third, that the moral demand of external freedom should be universally cosmopolitan in its legal application, regardless of race, nationality, social status, religious belief or other particularisms.

Nevertheless, understanding that Kant offers scant detail regarding the institutional arrangements necessary for a functioning cosmopolitan order, the authors fill this lacuna by outlining a combination of domestic, international and cosmopolitan legal structures necessary to render a CLO as a condition of public right. As part of this effort, Stone Sweet and Ryan outline two necessary conditions: (1) the existence of a transnational system of human rights protection (fulfilling CLO points 1 and 2 above); and (2) a condition of constitutional pluralism (fulfilling CLO point 3 above). This

16 See (n 12). 
latter condition is institutionally grounded via arguments for 'source pluralism' (two or more autonomous sources of judicially enforceable rights that coexist within domestic orders) and 'jurisdictional pluralism', which when combined create discrete hierarchies between national and treatybased courts 'capable of asserting their own respective autonomy and legitimacy, on the basis of separate legal instruments'.

By adding this final pluralist component, A Cosmopolitan Legal Order seeks to address three shortcomings usually associated with Kant's tripartite of cosmopolitan law. First, the CLO responds to the critique that there can be no authoritative legal source for Kantian justice without an authoritative world state (something Kant consistently rejected after 1793). In response, under a CLO, legal authority is maintained via a mix of national courts and treaty-based global commitments that, according to the authors, both enhances legal effectiveness and results in the emergence of a nascent treaty-based constitution representative of cosmopolitan right (Kant's ultimate ideal condition - and note that Perpetual Peace was written in the form of a treaty). Second, the pluralist component of the CLO satisfies Kant's demand for a voluntarist federation of individual states, from which states remain self-legislators (Willkür) while co-constituting a mutually consistent condition of external freedom (cosmopolitan right). Lastly, the jurisiterative CLO accommodates Kant's unwillingness to frontload predictions about the final institutional complexion of a cosmopolitan order, thus adopting Kant's suggestion for a 'gradual' and iterative form of constitutionalization, ${ }^{18}$ 'which may eventually be regulated by public laws, thus bringing the human race nearer and nearer to a cosmopolitan constitution'. ${ }^{19}$ As Benhabib suggests in her contribution, Stone Sweet and Ryan seemingly render a Kantian form of dialogic constitutionalism, with the aim that the iterative development of a 'cosmopolitan commons' will be able to 'mediate the republican ideal of self-government with the trusteeship role of the courts'. (Benhabib remains cautiously optimistic.)

In order to ground Kant's theory in practice, Stone Sweet and Ryan argue that such a Kantian CLO emerged in post 1998 Europe as a product of the combined constitutionalization effects of Protocol no. 11 of the European Convention on Human Rights (ECHR) (individual applications directly to the ECtHR) as well as the incorporation of the ECHR into national law (the basis of constitutional pluralism). Protocol no. 11 (together with Protocol No. 14) established a fundamental change in the machinery of the ECHR.

17 See (n 8) 82.

18 Immanuel Kant, 'Perpetual Peace' in H Reiss, Kant's Political Writings (Cambridge University Press, Cambridge, 1970) 104 [8:356]

19 Ibid, 108 [8:360-1]. 
The ECtHR was given compulsory jurisdiction and states could no longer ratify the ECHR without accepting the jurisdiction of the ECtHR; the judicial functions of the Committee of Ministers (which is a political body) were also abolished. This enhanced the effectiveness of the Convention, since it sought to address chronic failures of rights protection at the national level (thus intersecting Kantian foundations for co-constrained domestic and international right). Incorporation made Convention rights directly enforceable by national judges, as a matter of domestic law. By doing so, it is argued that Convention rights further ground the necessary Kantian interlink between domestic justice, international justice and enforceable legal mechanization, from which a condition of external freedom (public right) can ultimately be adjudicated.

This resulting system is governed by what Stone Sweet and Ryan call a 'decentralized sovereign'- namely, a community of courts whose activities are coordinated through the rulings of the European Court, based in Strasbourg. Although imperfect and still maturing, Stone Sweet and Ryan argue that the regime meets significant criteria of legal effectiveness, which is often a critique made against Kantian legal theorists and cosmopolitans more broadly. Furthermore, in responding to Kant's 'authority problem', Stone Sweet and Ryan highlight that the ECHR regime routinely succeeds in raising standards of rights protection and has helped to anchor transitions to constitutional democracy in post-authoritarian states (intersecting Kant's tripartite of law - domestic, international and cosmopolitan right). Moreover, in line with Kant's prognosis of a 'gradual furtherance' of cosmopolitan right, the ECtHR has steadily developed the capacity to render justice to all persons who come under the jurisdiction of member states, even non-citizens who live - and whose rights are violated - beyond Europe (fulfilling elements of Kant's cosmopolitan right and laws of hospitality - see Bjorge). ${ }^{20}$ Today, the authors argue, the ECHR comprises an important component of an emerging cosmopolitan constitution, while the ECtHR represents the single most active and important rights protecting body in the world (representing a form of emerging cosmo-constitutionalization). The importance of this final point is echoed by two of the contributing authors in this symposium, namely, that the ECtHR influences a number of states (Po Jen Yap) and an increasing number of regional human rights bodies (Sandholtz), in which it is possible to interpret the potentiality for a cross-cultural and interjurisdictional cosmo-constitutionalization. Bjorge concludes that the ECtHR is indeed a cosmopolitan legal order and, moreover, the only international legal order ever properly to have attained those characteristics.

${ }^{20}$ See Bjorge's contribution to this symposium. 
Although the book presents a compelling and well-argued position, it will no doubt have its detractors. In terms of its use of Kant, one expected criticism of the book involves ongoing debates about how to understand the relationship between Kant's notions of internal and external freedom, human dignity and public right. For some, it will be deemed inappropriate to simply associate contemporary notions of human rights with Kant's discussion of public right, because it is argued that Kant was concerned primarily with grounding internal moral duties towards a condition of justice (public right), not necessarily with the protection of personal entitlements, as are many modern right-based theories and the ECtHR. ${ }^{21}$ For others, the key to understanding public right rests in Kant's commitment to republicanism as the ultimate source of external freedom and not, as others have claimed, a natural law reading of pre-political inalienable rights. ${ }^{22}$

Alternatively, like Stone Sweet and Ryan, others argue that Kant either explicitly demands the protection of 'innate rights', which are closely synonymous with our current understanding of human rights, ${ }^{23}$ or that Kant maintained a natural law understanding of human moral dignity, which demands legal codification into human-based law. ${ }^{24}$ From these readings, it is often argued that there are strong correlations between Kant's metaphysical foundations for the legitimate conditions of justice and contemporary treatments of human rights law.

To be clear, and in defence of A Cosmopolitan Legal Order, it is doubtful that there will ever be full agreement on whether or not it is appropriate to advance a human rights reading of Kant. As has been argued elsewhere, there is textual and secondary evidence to support each of the aforementioned claims, with many of us remaining agnostic on the subject. ${ }^{25}$ Even in terms of trying to locate a preponderance of textual evidence, there are simply too many tensions in Kant's writings, which allow for multifarious viable readings. Moreover, Kant is often ambiguous in his contemporaneous reflections on debates about 'the rights of man' and its manifestations in the American and French revolutions. For many of us, the best option is to merely suggest that the final answer on the human rights debate remains open, but that in

21 Onora O’Neill, 'Transnational Justice' in Political Theory Today, edited by David Held (Polity Press, Cambridge, 1995) 276-304.

${ }^{22}$ Kjartan Koch Mikalsen, 'Kantian Republicanism in the International Sphere: Equal Sovereignty as a Condition of Global Justice' in Kant's Cosmopolitics, edited by Garrett Wallace Brown and Áron Telegdi-Csetri (Edinburgh University Press, Edinburgh, 2019); see also Benhabib's contribution in this issue.

${ }^{23}$ Sharon Anderson-Gold, Cosmopolitanism and Human Rights (University of Wales Press, Cardiff, 2001).

${ }^{24}$ Charles Jones, Global Justice: Defending Cosmopolitanism (Oxford University Press, Oxford, 1996).

${ }^{25}$ See (n 10) 59-66, 198-202. 
exploring a Kantian form of cosmopolitan law, it is still heuristically valuable to investigate whether human rights are a reasonable method to politically organize individuals and states into a legal condition of public right. In other words, although Kant may or may not have envisioned human rights as we currently understand them, rights are existing legal inventions that can contribute to the institutionalization of public right. In addition, human rights seemingly have the capacity to intersect with and harmonize Kant's tripartite levels of intra-state, inter-state and cosmopolitan law (as depicted in the CLO). This ability to harmonize the legal tripartite is a necessary feature of Kant's cosmopolitanism, and he makes this perfectly clear when he claims that 'if the principle of outer freedom limited by law is lacking in any one of these three possible forms of rightful condition, the framework of all the others is unavoidably undermined and must finally collapse'. ${ }^{26}$ Given the fact that human rights (as we know them today) allow embryonic intersections to exist between Kant's tripartite of law (see Po Jen Yap's contribution on the importance of Kant's first definitive article - republicanism), it is foolhardy not to explore the heuristic value of a Kantian rights-based approach (whether or not this was his original intent), especially if this exploration can resonate more fully with what Jürgen Habermas calls our 'lifeworld'. ${ }^{27}$ Nevertheless, taking a reconstructive rights-based approach will induce another potential methodological objection to A Cosmopolitan Legal Order, since it will no doubt raise heckles of strict Kant scholars who lament 'neo-Kantian appropriations' that fill in too many voids with exogenous material and/or that do not remain fixated on the existing internal logic of Kant (with corresponding exegetical compliance).

Again, there are reasons to suggest that holding this methodological viewpoint is too narrow-minded and that a proper division of 'Kantian' labour is still useful. First, in plain language, such a narrow methodology simply stifles political imagination and any reasonable effort to apply Kant's ideas and careful approximations of his work to contemporary debates. Although Kant could not have imagined the world as it is today, this does not necessarily mean his ideas have no value for our current thinking. Second, exegetical strictness in many ways goes against Kant's own ideas about enlightenment and human progress. This is because Kant himself suggested an evolutionary nature to political development towards a kingdom of ends, which he suggests required multiple generations and continuous moral and political reflections and innovations. ${ }^{28}$ As Kant argues, progress requires

${ }^{26}$ Immanuel Kant, The Metaphysics of Morals (Cambridge University Press, Cambridge, 1996 [1797]) 89 [6:311].

27 See (n 12).

${ }^{28}$ See $(\mathrm{n} 10) 22$. 
'incalculable series of generations, each passing on its enlightenment to the next'. ${ }^{29}$ Furthermore, Kant encourages us to 'abstract at the present from current hindrances, which . . . are occasioned by the neglect of genuine ideas'. ${ }^{30}$ Third, as others have argued, there is nothing disingenuous or fanciful about 'making use of Kant to go beyond Kant', ${ }^{31}$ since this is part and parcel of the history of political ideas and to claim otherwise would be to deny a key driver of historical change. Fourth, in terms of the type of exploration found in A Cosmopolitan Legal Order, there is textual evidence to suggest that Kant himself invited us to think imaginatively with his own unfinished cosmopolitan ideas. As Kant stated in the appendix to his essay Perpetual Peace (his most applied vision of cosmopolitan order), 'as for cosmopolitan right, I pass over it here in silence, for its maxims are easy to formulate and assess on account of its analogy with international right' ${ }^{32}$ If nothing else, this statement demonstrates Kant's willingness to allow others to help finish his thoughts about the 'principle of public right' and to think through his ideas in application beyond what he was able to do in his lifetime. Lastly, as has been argued elsewhere, there is methodological coherence in making a distinction between what Kant may have actually believed (if that is possible to know) and a 'reconstruction that consciously attempts to capture his best-known philosophical tenets'. ${ }^{33}$ The key to legitimating this latter approach is to be forthright about what is being directly attributed to Kant and what is being augmented or reworked in line with his well-known precepts in a deliberate attempt to move the argument forward.

Thus, in regard to the appropriateness of using Kant for contemporary expressions of legal cosmopolitanism, it is clear that the arguments posited in A Cosmopolitan Legal Order represent what Stone Sweet and Ryan readily disclose as a 'Kantian-congruent' exploration in the fashion outlined above. More specifically, the book represents an analysis in which the political and legal dynamics of the ECHR are explained as congruent with a Kantian cosmopolitan framework. Although this may not strictly reflect Kant the cosmopolitan (see Sadurski's concern about this in this issue), it nevertheless reflects Kant's cosmopolitanism ethos writ large, despite and in response to Kant's ambiguities and inconsistencies. ${ }^{34}$ This exercise not only helps to situate Kant's theories in contemporary practice (and vice versa),

\footnotetext{
29 Immanuel Kant, 'Idea for a Universal History with a Cosmopolitan Purpose', in H Reiss, Kant's Political Writings (Cambridge University Press, Cambridge, 1970) 43 [8:19].

${ }^{30}$ Immanuel Kant, The Critique of Pure Reason (Colonial Press, London, 1900) [4:201].

${ }^{31}$ See Hoffe (n 10) 6 ; see also Corradetti's contribution to this issue.

32 See (n 18) 128 [8:384].

33 See (n 10) 21.

${ }^{34}$ See Corradetti's contribution in this issue.
} 
but also provides us with the opportunity to think creatively about the emergence of a cosmopolitan legal order more broadly and its substantiation in both theory and practice. In light of rising tensions between neosovereigntists and cosmopolitans, the book ultimately offers an important advancement in our thinking about the role of existing law, human rights, cosmo-constitutionalization and the possibility for the advancement of meaningful global constitutionalism.

Finally, scholarly purity bordering on historicism will exclude Kant scholars from the field. Applied research, particularly when other academic disciplines are involved, no doubt has its own challenges. Nevertheless, it will make important contributions to the development of political and judicial institutions at the domestic and international levels. This is important especially since lawyers as advisers to states and international organizations, judges, other kinds of practitioners and legal scholars are inherently oriented towards systemic coherence and incremental development, ${ }^{35}$ and will look to new ideas to help adapt to the emergence of a legal order analysed in $A$ Cosmopolitan Legal Order. This has practical merit, since they are only one group of the book's prospective users (and abusers).

As with all research, the decisive question for reflection is: Does this form of applied research, in interaction with more traditional academic Kant scholarship, have anything meaningful to say? The motivation for our symposium in Global Constitutionalism was to engage with and better explore the theoretical implications and practical legal ramifications of $A$ Cosmopolitan Legal Order. The six contributors to this issue were selected based on their specialist expertise on Kantian legal theory, human rights law and/or global constitutionalism. In commissioning the contributions, we simply sent each author a copy of the book and asked them to focus on a particular aspect of Stone Sweet and Ryan's argument that resonated with their own interests or that sparked concern. As a result, the contributions in this symposium reflect a wide range of specialist examinations and therefore there is no overarching theme. That said, two broad themes naturally emerged; these are discussed below.

\section{The CLO and its universal scope}

A number of authors sought to investigate the universal applicability of Stone Sweet and Ryan's particular form of CLO. Po Jen Yap argues that

\footnotetext{
35 Armin von Bogdandy, Matthias Goldmann and Ingo Venzke, From Public International to International Public Law: Translating World Public Opinion into International Public Authority, Research Paper No. 2016-02 (Max Planck Institute for Comparative Public Law \& International Law, Heidelberg, 2016).
} 
there are promising signs regarding the use of proportionally analysis in Asia. As he outlines, European-styled proportionality analysis is evident in both the Taiwanese and South Korean judicial systems, with a number of important adjudications underscoring its potency, as suggested of a CLO. Yet Yap warns that these Asian examples are seemingly linked exclusively to democratic states, since there is no meaningful use of proportionality in authoritative Asian regimes such as China or Singapore. His contribution thus champions the ability of proportionality analysis to act as a generalizable tool for cosmo-constitutionalization outside of Western contexts, but he warns that it is dependent on democratic states - something Kant also claimed to be a necessary condition for a cosmopolitan legal order under his first definitive article.

To broaden the potentiality for a CLO beyond the ECtHR, Wayne Sandholtz argues that there are promising signs of cosmo-constitutionalism within a number of key global and regional human rights instruments. In outlining the potential for a larger CLO, Sandholtz suggests that there exists a form of 'judicial dialogue among the regional human rights courts' and that this creates an informal and decentralized coordination mechanism. Sandholtz argues that this allows an environment for increased institutionalization and constitutionalization between a plurality of legal mechanisms and adjudications, which in line with the ECtHR 'provide a model and focal point for the emergence of transregional constructions of rights review'.

In many ways the arguments of Po Jen Yap and Sandholtz offer a reasonable response to critics, who will argue that the ECHR and ECtHR merely represent a European affair born of a particular regional history with a unique set of philosophical traditions. First, as Sandholtz notes, the ECHR reaches beyond European Union member states in terms of signatories, which suggests that the ECHR's influence is not necessarily confined to being merely a European project. Therefore, although the ECHR certainly comes from a 'particular place', its appeal can resonate beyond that place, becoming diffused, adapted, amalgamated and implemented within new global contexts - which, as Kant rightly notes, is how cosmopolitical foundations will ultimately 'spread further and further' over time. Second, as argued by a number of contributors, the CLO as outlined by Stone Sweet and Ryan is explicitly Kant-congruent and thus tightly bound within that internal logic. As a result, in line with Kant, the CLO must begin by exploring Kant's transitional legal mechanisms and then move forward to locate practices that exhibit nascent transboundary characteristics, which can transcend existing regional politics in theory and practice. Again, this transitional iterative process is exactly how Kant himself envisaged the development of any CLO, arguing that a CLO would need to spread organically (not to be imposed from above), from ideas of a single 
enlightened state or from a small group of like-minded states. From this standpoint, the CLO delivered by Stone Sweet and Ryan does exactly what it promised. Namely, it provides an outline of an emerging Kantian based CLO as witnessed in the ECHR and its court, which has foundational properties that are consistent with Kant's vision, but also capable of expansion - albeit still within Kant's overall normative demands. Moreover, beyond the formal mechanisms of the ECHR and its court, Sandholtz argues that the ECtHR has influenced a number of regional human rights bodies, again suggesting that the ECtHR exhibits transitional properties that can, over time, provide opportunities for the emergence of an expanded CLO. Lastly, Po Jen Yap outlines how CLO-congruent proportionality can be witnessed in Asia, which suggests that there is promise for the non-European adoption of a key CLO foundation. Yet, as outlined above, Yap exposes a crucial empirical link between democratic states and proportionality. To some this will be seen as limiting the potential reach of the CLO, rendering the CLO a 'separate peace' more than a promising cosmopolitan project. However, it is again important to reflect upon what is being offered in the analysis of the CLO. For Kant, as well as for Stone Sweet and Ryan, the aim is to provide a cosmopolitan blueprint, one that can locate key cosmopolitan ingredients (such as democracy) as well as potential legal pathways. What the analysis of the CLO delivers is both: a set of key moral foundations backed by legal procedures, which when combined, fulfils the basic tenets of Kant's cosmopolitan vision. Neither Kant nor the authors in this symposium would dare to claim that the CLO has reached a fully-fledged cosmopolitan legal order, or that a cosmopolitan global constitution will teleologically materialize from its foundations. The claim is merely that there is a nascent CLO in existence, with unique cosmopolitan potential, from which we can learn and draw enthusiasm from in an effort to rethink an emerging global constitution and ongoing processes of global constitutionalization writ large.

Further broadening the reach of the CLO, Eirik Bjorge's contribution concerns two discrete aspects of Stone Sweet and Ryan's theory: (1) what the Kantian CLO means for an international court; and (2) what it means for the holders of the rights that flow from the cosmopolitan legal order. $\mathrm{He}$ compares the ECtHR with the CJEU, before turning to the extent to which, in order to be considered a truly cosmopolitan legal order, the European Convention needs at times to not only make non-citizens free of rights equal to those of citizens, but also to give them stronger rights than those enjoyed by citizens. Bjorge concludes that the ECtHR is indeed a cosmopolitan legal order and, moreover, that it is the only international legal order to have properly attained those characteristics. He concludes with one of the ideas on which the authors end their study: the meaning of the European 
Convention beyond its European context. Many writers have touched on variations of this question. The French post-war statesman Louis Armand, for example, wrote in 1968 that 'L'Europe n'est plus l'Europe mais seulement un morceau du monde. ${ }^{36}$ Bjorge cites Kant's The Contest of Faculties on the French Revolution: if it is difficult to prove progress in history, the study of history nevertheless allows the observer to discern signs that real progress is possible. The French Revolution was such a sign - what happened in France in 1789 had until then been entirely unthinkable: men and women raising the standard of revolt in the face of the power of the king. More important than the reality of the French Revolution, however, was the enthusiasm engendered by the fact that it came into being. This, Bjorge argues, applies to the ECHR and the ECtHR. The European system for the protection of human rights and fundamental freedoms may fail or succeed, yet the enthusiasm that this single most successful rights-protecting body in the world has created in bystanders, and the very fact that it came into being, prove that real progress is possible. Bjorge concludes that, from a Kantian perspective, this may well be its greatest accomplishment.

\section{Tensions between the CLO and self-determination}

A theme present in all contributions was a concern about the delicate balance struck by the CLO between the universal rights-based adjudicative power of the trustee courts and the role of state self-determination allowed within constitutional pluralism. For Sadurski, there is a concern that the CLO too easily abandons Kant's concern about determining the right reasons for restricting freedom under a condition of public right. Although Sadurski does not use the language below, he does suggest that Kant places considerable justificatory weight on the principle of publicity, which outlines appropriate negative and positive political motivations to determine the legitimacy of a legal maxim. The negative test relates directly to identifying maxims that morally violate the principle of public right and are thus immediately deemed inappropriate for domestic law, international law and cosmopolitan law. Correspondingly, the positive test is to identify maxims that are both consistent and complementary with the interest of public right. Through this, the principle of publicity asserts that maxims that do not fail the test, or in fact promote public right, are required to be made public and are therefore 'reconciled with both right and politics'. ${ }^{37}$ Accordingly, Kant further maintains that maxims that can satisfy this rule also 'conform to the

\footnotetext{
36 Bernard Stirn, Towards a European Public Law (trans Eirik Bjorge, Oxford University Press, Oxford, 2017) 182.

37 See (n 18) 130 [8:386].
} 
universal aim of the public' ${ }^{38}$ If this is so, then it raises a concern that a ECtHR-based CLO, as outlined by Stone Sweet and Ryan, remains too deferential in accepting at face value the motivational legitimacy of states in restricting rights (freedoms). In contrast, Sadurski argues, 'a Kantian perspective on the ECtHR would call for attention to the Court's scrutiny of member states' reasons for legislation expressed in the quality of the aims they pursue, while putatively engaging Convention rights'. The implications for a CLO, as implied by Sadurski, is that it surrenders too much ground, thus weakening the ECtHR's cosmopolitan potential as well as its Kantian foundations.

Alternatively, looking from the bottom up, Benhabib relates a concern that the CLO underplays the importance Kant places on republican and selflegislated law. Unlike Sadurski's concern about the trustee court being too weak, Benhabib suggests that the CLO overly 'slants' Kant's cosmopolitanism toward 'courts and judicial supremacy'. Moreover, argues Benhabib, it is not clear how trusteeship power over legislative practices is delegated by the people who are subject to its jurisdiction, nor why this form of judicial review would have any democratic legitimacy. Despite these concerns, Benhabib remains cautiously optimistic about the ability of the CLO to render issues of state self-determination and human right's trusteeship compatible. This is especially so, argues Benhabib, if we understand the CLO as a form of dialogic constitutionalism. By dialogic constitutionalism, it is important to understand the CLO not as 'authoritative' per se, but 'editorial', in that it maintains the necessary 'guardrails' to protect a selflegislated system of rights, where the protection of certain personal freedoms associated with autonomous self-law giving would be mandatory.

Corradetti explains the ECHR and the ECtHR as a representation of a transitional form of cosmopolitanism and a realistic progression toward a Kantian cosmopolitan constitution and perpetual peace. He accepts the views of Stone Sweet and Ryan on the Strasburg Court as a legitimate update of the Kantian project. He highlights how Stone Sweet and Ryan sees the ECtHR as an "omnilateral trustee" court which safeguards citizens' basic rights without emptying the authoritative power of states. In doing so, Corradetti supports Stone Sweet and Ryan's moderate 'transitional' reading of cosmopolitan law, which he suggests can better satisfy state-based selflegislation while legitimizing external relations between states. Four principles balance domestic sovereignty and international authority: proportionality, subsidiarity, the margin of national appreciation, and consensus of states. Without subscribing to all aspects of Stone Sweet's and Ryan's argument, Corradetti maintains that a poliarchy of transnational

38 See (n 37). 
arrangements (not only courts) best promotes a Kantian project among global constitutional trajectories, which also fits well into Habermas's transitional model. ${ }^{39}$

\section{A CLO for the future?}

The authors in this symposium find support for the emergence of, and increasing prospects for, Alec Stone Sweet and Clare Ryan's CLO. The investigation into the applicability of Stone Sweet and Ryan's particular form of CLO goes beyond Europe. At the same time, the authors in the symposium recognize broad-based critiques against the CLO, perceive the tensions that exist in its practice and voice concerns about its future in Europe and at a global level, not the least from the neo-sovereigntist position increasingly adopted in the United States and elsewhere. As we mentioned at the outset, current populist challenges are testing both the European Court of Human Rights and the idea of an expanding CLO. Yet the aim here is not to predict the future trajectory of human rights, the ECHR or the future of cosmopolitanism, since this would go beyond the scope of this symposium.

Particularly in terms of the universal appeal of the CLO, we can emphasize the importance of reflecting upon Kant's logic and the history of cosmopolitan thinking more generally - namely, the basic cosmopolitan principle regarding the universal value of human dignity that has been in existence much longer than many of its theoretical alternatives (since Akhnaton in 1375 BCE, for example), including notions of state sovereignty. As a result, any confident prediction of the demise of cosmopolitanism should be viewed with suspicion, since it represents a rather ahistorical position that ignores historical resilience. Moreover, as Kant rightly claims, we live on a bounded sphere. This is an empirical reality that, as Kant claims, 'provides the occasion for troubles in one place on our global to be felt all over'. ${ }^{40}$ Under globalization, these troubles have now become painfully acute - far more so than Kant could have imagined in 1793. If nothing else, what was true then is even more true now, and the CLO offers a blueprint for how it might be possible to move from 'current hindrances' to a civil order that can administer justice universally. In this light, 'the idea of cosmopolitan right [under a CLO] is not fantastic or overstrained; it is a necessary complement to the unwritten code of political and international right, transforming it into a universal right of humanity'. ${ }^{41}$

\footnotetext{
39 See (n 13).

40 See (n 26) 121 [6:353].

41 See (n 18) 108 [8:360].
} 